\title{
Olyreae (Poaceae: Bambusoideae) da Marambaia, Rio de Janeiro, Brasil
}

\author{
Olyreae (Poaceae: Bambusoideae) of Marambaia, Rio de Janeiro, Brazil
}

Christian da Silva ${ }^{1,4}$, Marilena de Menezes Silva Conde ${ }^{2} \&$ Hilda Maria Longhi-Wagner ${ }^{3}$

\begin{abstract}
Resumo
A Marambaia localiza-se no sul do Estado do Rio de Janeiro, entre a Baía de Sepetiba e o Oceano Atlântico, nos domínios da Mata Atlântica. Os representantes da tribo Olyreae constituem os bambus herbáceos e são encontrados, principalmente, nos trópicos do Novo Mundo, geralmente compondo o estrato herbáceo de matas, estando por isso ameaçados pela degradação ou fragmentação de habitats. O presente estudo objetivou levantar as espécies de Poaceae pertencentes à tribo Olyreae que ocorrem na área de estudo e contribuir para o conhecimento da sua diversidade, distribuição e conservação. As coletas foram realizadas de agosto de 2008 a dezembro de 2010, através de caminhadas livres ao longo de trilhas nas diversas formações vegetais. Foi verificada a ocorrência de sete espécies da tribo Olyreae, distribuídas, principalmente, nas áreas de floresta atlântica de encosta. A subtribo Olyrineae está representada por Cryptochloa capillata, Olyra humilis, O. latifolia, Parodiolyra micrantha, Raddia brasiliensis e Reitzia smithii, e a subtribo Parianinae, por Eremitis sp. Olyra latifolia e P. micranta são as espécies mais comuns na área. Eremitis sp. provavelmente se constitui em uma nova espécie.

Palavras-chave: Floresta Atlântica, bambus herbáceos, Olyrinae, Parianinae.
\end{abstract}

\begin{abstract}
Marambaia is located in southern Rio de Janeiro state, between Sepetiba Bay and the Atlantic Ocean $\left(23^{\circ} 1^{\prime} \mathrm{S}\right.$, $23^{\circ} 6^{\prime} \mathrm{S}$; $43^{\circ} 34^{\prime} \mathrm{W}, 44^{\circ} \mathrm{W}$ ), within the Atlantic Forest domain. The tribe Olyreae includes the herbaceous bamboos, found mainly in the New World Tropics, usually comprising the herbaceous layer of forests. They are being threatened by habitat fragmentation and degradation. This study aims to determine which Olyreae species occur in the area, contributing to our knowledge of their conservation, distribution and diversity. Samples were collected from August 2008 to December 2010 by free walks along trails in the various plant formations. The occurrence of seven Olyreae species distributed in Atlantic slope-forest areas was confirmed. Subtribe Olyrinae is represented by Cryptochloa capillata, Olyra humilis, O. latifolia, Parodiolyra micrantha, Raddia brasiliensis and Reitzia smithii, and subtribe Parianinae by Eremitis sp. Olyra latifolia and P. micrantha are the most common species in the area. Eremitis sp. is probably a new species.
\end{abstract}

Key words: Atlantic Forest, herbaceous bamboos, Olyrinae, Parianinae.

\section{Introdução}

A família Poaceae figura entre as cinco maiores famílias de angiospermas, ocupando a quarta posição, com aproximadamente 10.000 espécies em mais de 700 gêneros (GPWG 2001). As gramíneas ocorrem em todas as regiões geográficas do mundo (Longhi-Wagner 2011) e são importantes para o homem devido as suas várias utilidades, como por exemplo, o arroz (Oryza sativa L.) e o trigo (Triticum aestivum L.), cereais amplamente utilizados por diversas culturas. Atualmente, esta família apresenta-se dividida em doze subfamílias (Clark 2009; Sánchez-Ken \& Clark 2010), dentre estas, Bambusoideae, com aproximadamente 1.200 espécies (GPWG 2001). Esta subfamília constituise num grupo monofilético e suas espécies estão distribuídas em três tribos: Bambuseae (bambus lignificados tropicais), que é grupo irmão de

\footnotetext{
${ }^{1}$ Universidade Estadual de Feira de Santana, Av. Transnordestina s/n, Depto. Ciências Biológicas, 44036-460, Feira de Santana, BA, Brasil.

${ }^{2}$ Universidade Federal Rural do Rio de Janeiro, Instituto de Biologia, Depto. Botânica, Campus Seropédica, Rodovia BR-465, km 7, 23851-970, Seropédica, RJ. ${ }^{3}$ Universidade Federal do Rio Grande do Sul, Instituto de Biociências, Depto. de Botânica, Av. Bento Gonçalves 9500, prédio 43323, Agronomia, 91501-970, Porto Alegre, RS, Brasil.

${ }^{4}$ Autor para correspondência: christian_da_silva@hotmail.com
} 
Olyreae (bambus herbáceos), formando com este um clado que é irmão de Arundinarieae (bambus lignificados temperados) (Sungkaew et al. 2009).

Os membros da tribo Olyreae ocorrem de $29^{\circ} \mathrm{N}$ a $34^{\circ} \mathrm{S}$ e são comuns nas florestas tropicais e subtropicais, especialmente do Novo Mundo, não atingindo as regiões temperadas ou frias, ou elevações superiores a 1.000 m (Calderón \& Soderstrom 1980; Zhang \& Clark 2000). A tribo compreende 21 gêneros distribuídos nas subtribos Olyrinae e Parianinae (Judziewicz et al. 1999; Zhang \& Clark 2000). De acordo com Judziewicz et al. (1999) e Filgueiras \& Santos-Gonçalves (2004) são citados para o Brasil cerca de 70 espécies distribuídas em 16 gêneros, sendo quatro destes (Reitzia Swallen, Sucrea Soderstr., Diandrolyra Stapf, Eremitis Döll) endêmicos da Mata Atlântica (Oliveira et al. 2006).

A Marambaia, localizada no estado do Rio de Janeiro, Região Sudeste do Brasil, faz parte do Bioma Mata Atlântica, hoje reduzido a $7 \%$ de sua cobertura original (Fundação SOS Mata Atlântica/INPE 2008), e abriga ecossistemas em bom estado de conservação, com grande riqueza em fauna e flora. Porém, a área voltada para a baía de Sepetiba vem sofrendo considerável pressão antrópica (Conde et al. 2005).

$\mathrm{Na}$ Marambaia são encontradas áreas de manguezal, restinga e floresta atlântica de encosta (Conde et al. 2005). No entanto, no último levantamento florístico realizado (Conde et al. 2005), só foram efetuadas coletas de gramíneas nas áreas de restinga, perfazendo um total de 15 espécies. Dentre estas, apenas Cryptochloa capillata (Trin.) Soderstr. e Olyra ciliatifolia Raddi pertencem à tribo Olyreae. O objetivo do presente estudo é estender este levantamento as demais áreas ainda não avaliadas da Marambaia.

\section{Material e Métodos}

Área de estudo

A Marambaia localiza-se na baía de Sepetiba, no estado do Rio de Janeiro, entre $23^{\circ} 1^{\prime} \mathrm{S}-23^{\circ} 6$ 'S e $43^{\circ} 34^{\prime} \mathrm{W}-44^{\circ} \mathrm{W}$, abrangendo os municípios do Rio de Janeiro, Itaguaí e Mangaratiba, numa área de 7.877,33 ha. Inclui duas áreas, uma denominada Restinga da Marambaia, e a outra, Ilha da Marambaia. O relevo varia de plano até $641 \mathrm{~m}$ de altitude, o Pico da Marambaia. O clima é ameno, com temperatura média anual de $23,6^{\circ} \mathrm{C}$ e precipitação média anual de $1027,2 \mathrm{~mm}$, sendo março o mês mais chuvoso, com 140,6 mm, e agosto o mais seco, com precipitação de $47,4 \mathrm{~mm}$ (Menezes \& Araujo 1999).

\section{Levantamento florístico}

Inicialmente, foi feito um levantamento bibliográfico geral sobre a área estudada, para reunir dados sobre a tribo em questão, bem como um levantamento nos Herbários GUA, R, RB e $\mathrm{RBR}$, para verificar possíveis registros para a área.

Os materiais foram coletados entre novembro de 2008 e dezembro de 2010, através de caminhadas livres ao longo de trilhas nas diversas formações vegetais existentes, num total de 15 expedições. Os espécimes foram fotografados no campo e em estereomicroscópio, sobre fundo de papel milimetrado, coletados, identificados e incorporados ao Herbário RBR.

A identificação foi realizada com bibliografia especializada e via comparações com exsicatas do Herbário RBR, ou foram feitas pela terceira autora. A terminologia descritiva e o modelo das descrições seguem Longhi-Wagner et al. (2001). As descrições dos gêneros são gerais, incluindo toda a variação observada e a citada na literatura, enquanto as descrições das espécies são baseadas no material coletado na Marambaia e nos materiais selecionados nos Herbários GUA, R, RB e RBR. As siglas dos herbários citados estão de acordo com Thiers (2010).

Para dados sobre períodos de florescimento, sinonímias, nomes populares e distribuição geográfica foram consultados a literatura específica, os dados dos espécimes coletados na área, e das etiquetas dos espécimes dos Herbários GUA, R, RB e RBR, além dos bancos de dados disponíveis on-line: Catalogue of New World Grasses (Soreng et al. 2000), Tropicos (MBG 2010) e GrassBase (Clayton et al. 2006). Também foi consultada a lista das espécies ameaçadas publicada pela IUCN (2001; 2011), a fim de levantar dados sobre o estado de conservação das espécies encontradas.

\section{Resultados e Discussão}

\section{Tribo Olyreae}

Plantas com rizomas curtos, colmos herbáceos ou sublignificados, folhas lanceoladas (excepcionalmente lineares) e pseudopecioladas, espiguetas unissexuadas distribuídas em diferentes partes, na mesma planta, e florescimento geralmente ao longo de cada ano (Calderón \& Soderstrom 1980; Soderstrom \& Zuloaga 1989; Oliveira et al. 2006).

$\mathrm{Na}$ Marambaia, a tribo Olyreae está representada por seis gêneros e sete espécies pertencentes às subtribos Olyrinae e Parianinae, que ocorrem no estrato herbáceo da área de floresta atlântica de encosta. 
As espécies aqui tratadas não foram incluídas entre as plantas raras do Brasil (Oliveira et al. 2009), nem na lista das espécies ameaçadas de extinção divulgada pelo MMA (2008), devido à relativamente ampla distribuição que apresentam. Exceção a isso é Reitzia smithi Swallen, pouco coletada e para a qual os dados ainda são deficientes (DD), de acordo com as categorias da IUCN (2001; 2010). Entretanto, Oliveira (2001) e Oliveira et al. (2006) já chamaram a atenção para a grande vulnerabilidade das espécies de Olyreae devido à fragmentação florestal e à consequente exposição das mesmas à intensa insolação.

\section{Chave de identificação para as espécies da tribo Olyreae na Marambaia}

1. Bainhas foliares fimbriadas no ápice; espiguetas estaminadas rodeando as pistiladas, em verticilos ... 6.1. Eremitis sp.

1’. Bainhas foliares sem fímbrias no ápice; espiguetas estaminadas e pistiladas isoladas.

2. Antécio pistilado estipitado. 1.1. Cryptochloa capillata

2'. Antécio pistilado não estipitado.

3. Antécio pistilado foveolado 3.1. Parodiolyra micrantha

3’. Antécio pistilado liso.

4. Espiguetas pistiladas e estaminadas em diferentes inflorescências

4.1. Raddia brasiliensis

4'. Espiguetas pistiladas e estaminadas na mesma inflorescência.

5. Inflorescência racemosa e contraída; antécio pistilado com manchas escuras na maturação; glumas com o ápice agudo a acuminado 5.1. Reitzia smithii

5'. Panícula laxa a subcongesta; antécio pistilado com ou sem manchas escuras na maturação; glumas, ao menos a inferior, com o ápice caudado a aristado.

6. Plantas 30-50 cm alt.; gluma inferior da espigueta pistilada com arista de 6-8 mm compr.; lema do antécio pistilado densamente piloso na base, nas margens e no ápice. 2.1. Olyra humilis

6'. Plantas 80-250(-400) cm alt.; gluma inferior da espigueta pistilada com arista de 11-23 mm compr.; lema do antécio pistilado glabro .. 2.2. Olyra latifolia

\section{Subtribo Olyrinae}

Plantas com bainhas foliares sem fímbrias no ápice e espiguetas estaminadas e pistiladas isoladas, distribuídas em diferentes partes da inflorescência ou em inflorescências distintas, na mesma planta. Compreende 18 gêneros neotropicais, dos quais 14 ocorrem no Brasil (Agnesia, Arberella, Cryptochloa, Diandrolyra, Froesiochloa, Lithachne, Olyra, Parodiolyra, Piresia, Raddia, Raddiella, Rehia, Reitzia e Sucrea) e quatro ocorrem no exterior (Ekmanochloa, Maclurolyra, Mniochloa e Piresiella), e um gênero monotípico paleotropical, Buergersiochloa, da Nova Guiné. Olyra latifolia L. e Parodiolyra micrantha (Kunth) Davidse \& Zuloaga foram aparentemente introduzidas na África, em Madagascar e nas Ilhas Fiji (Soderstrom \& Zuloaga 1989; Judziewicz et al. 1999; Soreng et al. 2000; Zhang \& Clark 2000).

\section{Cryptochloa Swallen}

Plantas perenes, monóicas, cespitosas, com rizomas curtos. Colmos eretos a decumbentes, com ou sem dimorfismo foliar. Bainhas foliares sem fímbrias no ápice; lâminas lanceoladas a oval-lanceoladas, base simétrica ou assimétrica. Inflorescências paniculadas ou racemosas, terminais e/ou axilares; espiguetas estaminadas e pistiladas geralmente na mesma inflorescência, ou em diferentes inflorescências. Espiguetas 1-floras, com flores unissexuadas. Espiguetas pistiladas com pedicelos pouco espessados no ápice ou não espessados, com desarticulação acima das glumas, que persistem na inflorescência após a queda do antécio maduro; entrenó entre as glumas inconspícuo, ápice da gluma inferior agudo ou atenuado; antécio estipitado, coriáceo, lanceolado, elíptico ou oval, comprimido dorsiventralmente, glabro, raramente pubescente, liso, às vezes 
tornando-se escuro e com manchas escuras na maturação. Espiguetas estaminadas menores do que as pistiladas, glumas ausentes; antécio linearlanceolado, elíptico ou oblongo, lema mútico ou aristado. Estames 3(-2).

Gênero com oito espécies distribuídas do México até Bolívia e Brasil (Judziewicz et al. 1999), representado por uma espécie na Marambaia.

\subsection{Cryptochloa capillata (Trin.) Soderstr.,} Brittonia 34: 202. $1982 . \quad$ Fig. 1a-d, 4a-c

Olyra capillata Trin., Mém. Acad. Imp. Sci. Saint-Pétersbourg, Sér. 6, Sci. Math., Seconde Pt. Sci. Nat. 3,1(2-3): 114. 1834.

Plantas cespitosas, eretas, $40-150 \mathrm{~cm}$; colmos herbáceos, glabros, levemente vináceos, nós glabros, com dimorfismo foliar. Bainhas foliares com tricomas curtos próximo ao ápice, ciliadas em uma das margens; lígula membranoso-ciliolada 1-3 mm compr., vinácea no bordo; pseudopecíolo $2 \mathrm{~mm}$ compr., com tricomas curtos; lâminas $7,2-23,5 \times 2-45,2 \mathrm{~cm}$, elíptico-lanceoladas a oblongo-lanceoladas, base arredondada, simétrica, ápice acuminado, glabra em ambas as faces, levemente vináceas na face abaxial. Panícula 9-13 $\times 3-8 \mathrm{~cm}$, aberta a subcontraída, terminal, às vezes acompanhada de inflorescências axilares parcialmente incluídas nas bainhas a exsertas; ramos inferiores subverticilados a alternos, com espiguetas estaminadas, com ou sem pistiladas terminais, ramos superiores alternos, com espiguetas estaminadas inferiormente e pistiladas terminais. Espiguetas pistiladas $12-21 \times 2-2,5$ $\mathrm{mm}$, lanceoladas, com pedicelos pouco espessados no ápice; glumas cartáceas, esverdeadas, glabras, 5-nervadas, a inferior com arista de ca. de $5 \mathrm{~mm}$ compr., a superior com arista de 2,5 $\mathrm{mm}$ compr.; antécio 9-10 × 1,5-2,2 mm, lanceolado, coriáceo, glabro, liso, esbranquiçado, sem manchas escuras na maturação, estipitado, estípete 1,5-1,7 mm compr., lema com o ápice agudo, encurvado. Espiguetas estaminadas $8,5 \times 0,8-1,0 \mathrm{~mm}$, linear-lanceoladas, glumas ausentes; antécio membranáceo, vináceo, levemente escabro, lema com arista de 2,8-3 mm compr., 3-nervado. Estames 3, anteras vináceas. Cariopse não vista.

Material selecionado: Mangaratiba, Ilha da Marambaia,

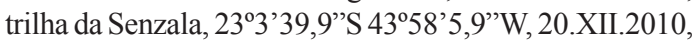
fl., C. Silva \& N.M. Corrêa 243 (RBR); Cachoeira da Gruta, 233'43,3”S 4358'34,7”W, 8.XI.2008, fl., C. Silva \& A.C.C. Moreira 47 (RBR); trilha para o Pico da Marambaia, 234' '1"S 4359'3,6"W, 19.III.2010, fl., C. Silva et al. 152 (RBR).
Material adicional examinado: BRASIL. RIO DE JANEIRO: Rio de Janeiro, Restinga do Grumari, 1.IV.1990, fl., D. Sucre \& M. Covas 11406 (RB); Floresta da Tijuca, 25.II.1972, fl., T.R. Soderstrom et al. 1850 (RB).

Espécie encontrada na Guiana Francesa e Brasil, na Amazônia e na Serra do Mar (Soreng et al. 2000; Clark \& Oliveira 2001). Na Marambaia é encontrada na floresta atlântica de encosta próxima a cursos d'água ou no interior da floresta, em indivíduos isolados ou formando pequenas populações, pouco comum. Sua ocorrência na área de estudo já havia sido referida por Conde et al. (2005). Coletada com flores de setembro a julho.

Cryptochloa capillata pode ser reconhecida pelas bainhas com o ápice vináceo, lâminas verdelustrosas na face adaxial e levemente vináceas na face abaxial, e pelas numerosas espiguetas estaminadas, de forte coloração vinácea.

\section{Olyra L.}

Plantas perenes, monóicas, cespitosas, com ou sem rizomas curtos ou alongados. Colmos eretos a decumbentes, às vezes apoiantes, sem dimorfismo foliar. Bainhas foliares sem fímbrias no ápice; lâminas lanceoladas a oval-lanceoladas, base simétrica ou assimétrica. Inflorescências paniculadas, terminais ou axilares, ramos inferiores com espiguetas estaminadas, com ou sem pistiladas terminais, os superiores com estaminadas inferiormente e pistiladas terminais. Espiguetas 1-floras, com flores unissexuadas. Espiguetas pistiladas com pedicelos espessados no ápice, com desarticulação acima das glumas que persistem na inflorescência após a queda do antécio maduro, às vezes posteriormente caducas; entrenó entre as glumas inconspícuo, ápice da gluma inferior acuminado, atenuado, caudado, mútico ou aristado; antécio estipitado ou não, coriáceo, lanceolado, elíptico, oblongo, oval ou oboval, comprimido dorsiventralmente ou cilíndrico, glabro ou piloso, liso, pontuado ou foveolado, com ou sem manchas escuras na maturação. Espiguetas estaminadas geralmente menores do que as pistiladas, glumas ausentes; antécio lanceolado ou elíptico, lema mútico ou aristado. Estames 3.

Gênero com 23 espécies neotropicais, distribuídas do México e sudeste dos Estados Unidos até a Argentina (Soderstrom \& Zuloaga 1989), representado por duas espécies na Marambaia. Apenas uma espécie, $O$. latifolia, é encontrada também na África e em Madagascar, havendo 


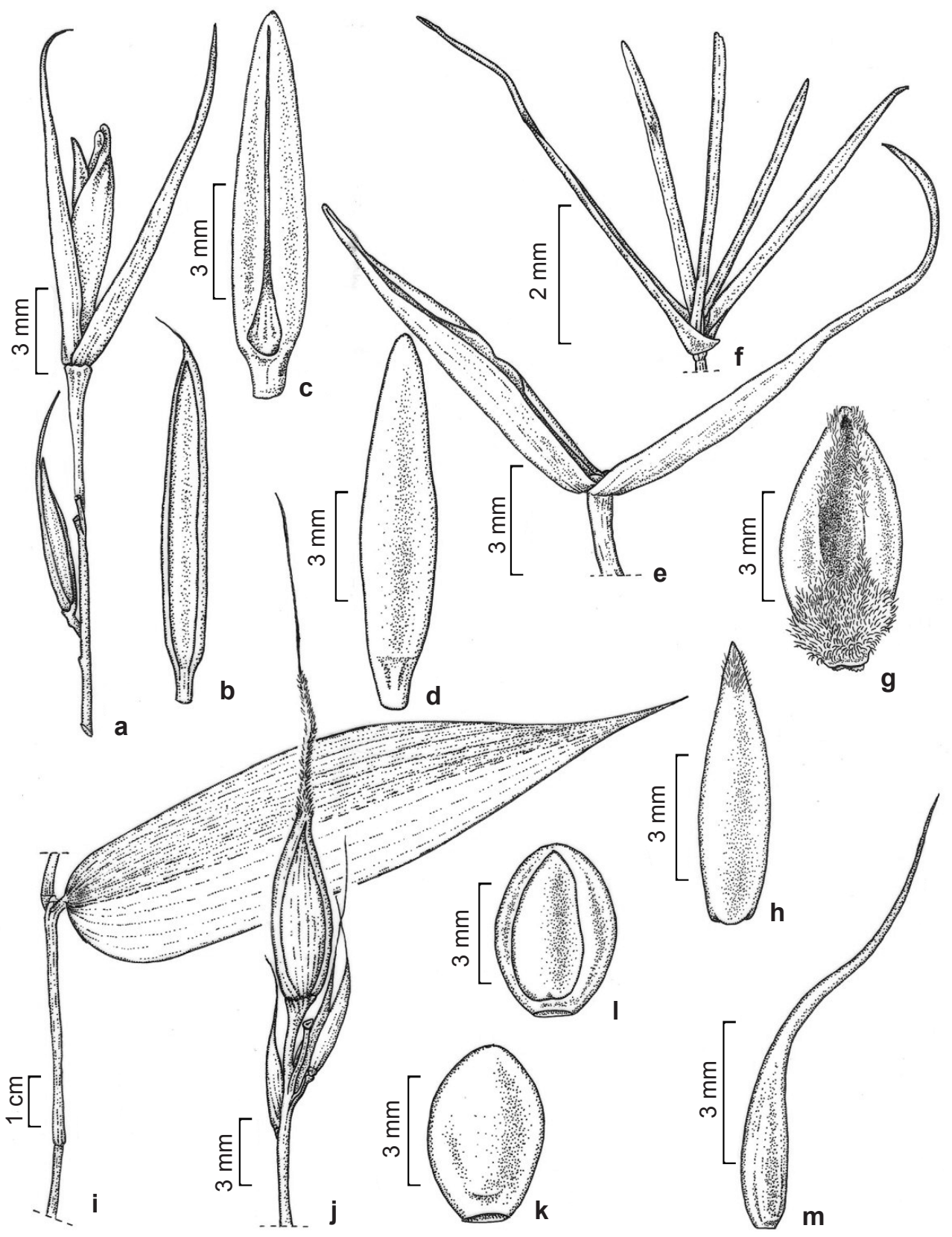

Figura 1 -a-d. Cryptochloa capillata (Trin.) Soderstr. - a. segmento de um ramo da panícula com uma espigueta estaminada e uma pistilada (apical); b. espigueta estaminada; c. antécio pistilado estipitado, vista ventral; d. antécio pistilado estipitado, vista dorsal. e-h. Olyra humilis Nees - e. glumas da espigueta pistilada; f. espigueta estaminada aberta, três estames; g. lema da espigueta pistilada, vista ventral; h. pálea da espigueta pistilada, vista dorsal. i-m. Olyra latifolia L. -i. folha; j. segmento de um ramo da panícula com três espiguetas estaminadas e uma pistilada (apical); $\mathrm{k}$. antécio pistilado, vista dorsal; 1 . antécio pistilado, vista ventral; $\mathrm{m}$. espigueta estaminada. (a-d C. Silva \& A.C.C. Moreira 47; e-h C. Silva \& A.C.C. Moreira 46; i-m C. Silva \& N.M. Corrêa 168).

Figure 1 -a-d. Cryptochloa capillata (Trin.) Soderstr.-a. panicle segment with one staminate spikelet and one pistillate (apical); b. staminate spikelet; c. pistillate anthecium with stipe, ventral view; d. pistillate anthecium with stipe, dorsal view. e-h. Olyra humilis Nees -e. glumes from a pistillate spikelet; f. open staminate spikelet, three stamens; g. lemma from a pistillate spikelet, ventral view; h. palea from a pistillate spikelet, dorsal view. i-m. Olyra latifolia L. - i. leaf; j. panicle segment with three staminate spikelets and one pistillate (apical); k. pistillate anthecium, dorsal view; 1. pistillate anthecium, ventral view; m. staminate spikelet. (a-d C. Silva \& A.C.C. Moreira 47; e-h C. Silva \& A.C.C. Moreira 46; i-m C. Silva \& N.M. Corrêa 168). 
dúvidas se é nativa ou foi introduzida (Soderstrom \& Zuloaga 1989). A espécie $O$. ciliatifolia foi previamente citada para a Marambaia por Conde et al. (2005) com base no exemplar D. Araujo 1726 (GUA), o qual, na verdade, corresponde à espécie Cryptochloa capillata, constituindo-se em um erro de identificação.

2.1. Olyra humilis Nees, Agrost. bras., in Mart., Fl. bras. enum. pl. 2: 304. 1829 Fig. 1e-h, 4d-f

Plantas cespitosas, eretas, com rizomas curtos, 30-50(-125) cm, colmos herbáceos, glabros, às vezes com tricomas curtos e esparsos (retrorsos), amarelados, nós glabros. Bainhas foliares com pontuações esverdeadas, curtamente pubescente; lígula membranoso-ciliada $2 \mathrm{~mm}$ compr.; pseudopecíolo $1 \mathrm{~mm}$ compr., densamente piloso; lâminas $4,2-11,5 \times 1,2-2,8 \mathrm{~cm}$, ovallanceoladas, base arredondada, assimétrica, ápice acuminado, faces adaxial e abaxial estrigosas, face abaxial esbranquiçada. Panícula 5-9 × 1,5-2 cm, subcongesta, pouco ramificada, terminal, exserta; ramos inferiores subverticilados, com espiguetas estaminadas, ramos superiores alternos, com espiguetas estaminadas inferiormente e pistiladas terminais, essas com os pedicelos espessados no ápice. Espiguetas pistiladas 13,5-20 × 2,8 mm, elíptico-lanceoladas; glumas cartáceas, esverdeadas, escabras, 7-nervadas, a inferior com arista de 6-8 $\mathrm{mm}$ compr., a superior longo-acuminada; antécio 6-7 × 2-2,5 mm, elíptico-lanceolado, coriáceo, com tricomas brilhantes na base, nas margens e no ápice, liso, esbranquiçado, com ou sem manchas escuras na maturação, sem estípete, lema com o ápice agudo, dorso da pálea com tricomas brilhantes no ápice. Espiguetas estaminadas $8,5 \times 1 \mathrm{~mm}$, linearlanceoladas, glumas ausentes; antécio membranáceo, hialino, com as nervuras esverdeadas, glabro, lema com arista de 2,5 mm compr., 3-nervado. Estames com anteras amareladas. Cariopse não vista.

Material selecionado: Mangaratiba, Ilha da Marambaia, cachoeira da bica, $23^{\circ} 3^{\prime} 28,2^{\prime \prime} \mathrm{S} 43^{\circ} 57^{\prime} 47,4^{\prime} \mathrm{W}$, 20.XII.2010, fl., C. Silva \& N.M. Corrêa 241 (RBR); Cachoeira entre a Praia da Caetana e a Praia da Pescaria Velha, 234'15,1"S 4359'47,9"W, 17.VI.2010, fl., C. Silva \& F.M. Ferreira 202 (RBR); Cachoeira da Gruta, 233'43,3”'S 4358'34,7'W, 8.XI.2008, f1., C. Silva \& A.C.C. Moreira 46 (RBR).

Material adicional examinado: BRASIL. DISTRITO FEDERAL: Fazenda Vargem Bonita, 5.II.1966, fl., H.S. Irwin et al. s.n. (RB 161747). MINAS GERAIS: Caxambu, 5.III.1929, fl., A. Sampaio 5946 (R). SANTA CATARINA: Abelardo Luz, 26 $6^{\circ} 50^{\prime} \mathrm{S} 52^{\circ} 20^{\prime} \mathrm{W}$,
23.X.1964, fl., L.B. Smith \& Pe. R. Reitz 12892 (R); Chapecó, 276'S 52 40'W, 15.X.1964, fl., L.B. Smith \& Pe. R. Reitz 12529 (R); Nova Teutonia, 29.I.1944, fl., F. Plaumann 323 (RB).

Espécie presente no Noroeste da Argentina, Brasil e Paraguai (Soderstrom \& Zuloaga 1989). $\mathrm{Na}$ Marambaia é encontrada na floresta atlântica de encosta próxima a cursos d'água, em indivíduos isolados, sendo pouco comum. Coletada com flores de outubro a junho, e em agosto.

Olyra humilis pode ser reconhecida pelas lâminas fortemente assimétricas e discolores, e inflorescências paucifloras, com espiguetas estaminadas amareladas. Assemelha-se à $O$. ciliatifolia Raddi e à $O$. glaberrima Raddi, duas espécies não encontradas na área de estudo mas que ocorrem em outras áreas de floresta atlântica do Estado do Rio de Janeiro. Olyra ciliatifolia diferencia-se por apresentar o antécio pistilado piloso em toda a extensão, e não apenas no ápice e na base. Olyra glaberrima apresenta maior porte, com numerosas espiguetas estaminadas de coloração vinácea. Dentre os herbários visitados, somente no RB foi encontrado um registro desta espécie para o estado do Rio de Janeiro. Este único registro indica que esta espécie tem sido pouco coletada ou não é muito comum em áreas de floresta atlântica.

2.2. Olyra latifolia L., Syst. Nat., ed. 10: 1261. 1759

Fig. 1i-m, 4g-i

Plantas cespitosas, eretas ou apoiantes, 80$250(-400) \mathrm{cm}$; colmos herbáceos a sublignificados, glabros, amarelados, às vezes com manchas vináceas, nós curtamente pilosos. Bainhas foliares pubescentes ou hirsutas, ciliadas ou não em ambas as margens; lígula membranosa $1 \mathrm{~mm}$ compr.; pseudopecíolo 1-3 mm compr., pubescente a densamente piloso; lâminas 7-22,5(-30) $\times$ $2-7,3(-9,7) \mathrm{cm}$, oval-lanceoladas a ovais, base arredondada, assimétrica, ápice acuminado, glabras em ambas as faces, às vezes pilosas na face abaxial, nervura central escabra na face abaxial. Panícula $7,5-11,5(-21) \times 2,5-6 \mathrm{~cm}$, laxa a subcongesta, terminal; ramos inferiores subverticilados a alternos, com espiguetas estaminadas, com ou sem pistiladas terminais, ramos superiores alternos, com espiguetas estaminadas inferiormente e pistiladas terminais. Espiguetas pistiladas 19-32 $\times$ 2,5-4 mm, oval-lanceoladas; glumas cartáceas, esverdeadas, glabras, 7-nervadas, a inferior com arista de 11-23 mm compr., a superior com arista 
de $8 \mathrm{~mm}$ compr.; antécio 5-6 × 2,7-3,5 mm, oval a elíptico, coriáceo, glabro, liso, esbranquiçado a castanho-escuro, com ou sem manchas escuras na maturação, sem estípete, lema com o ápice obtuso. Espiguetas estaminadas 6,5-8 $\times 0,8-1$ $\mathrm{mm}$, lanceoladas, glumas ausentes; antécio membranáceo, estramíneo, curtamente piloso, lema com arista de ca. de 2,5 mm compr., 3-nervado. Estames com anteras vináceas. Cariopse não vista. Material selecionado: Mangaratiba, Ilha da Marambaia,

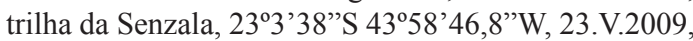
fl., C. Silva \& C.M.T. Silva 73 (RBR); trilha para a Gruta, 2303'39'S 4358'44,8”W, 23.V.2009, fl., C. Silva \& C.M.T. Silva 81 (RBR); trilha próxima à Praia do Sino,

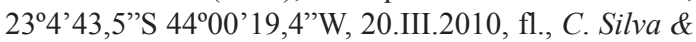
N.M. Corrêa 168 (RBR); trilha da Senzala, 8.XI.2008, fl., C. Silva \& A.C.C. Moreira 35 (RBR).

Material adicional examinado: BRASIL. ACRE: Rio Branco, VIII.1987, f1., Luetzelburg 21473 (R). AMAZONAS: Ariquemes, $10^{\circ} 35^{\prime}$ 'S 633ㄱ'W, 14.X.1979, fl., G. Vieira et al. 437 (RB). PARÁ: Itaituba, 2.V.1983, fl., I.L. Amaral et al. 1077 (RB). RIO DE JANEIRO: Barra do Piraí, Fazenda Paraíba, 19.V.1986, fl., J.P.P. Carauta et al. 5333 (GUA); Rio de Janeiro, Alto da Boa Vista, 6.I.1968, fl., D. Sucre 2112 (RB); Silva Jardim, Reserva Biológica de Poço das Antas, 24.X.1979, fl., D. Araujo 3372 (GUA).

Distribui-se na América Tropical, também encontrada na África e em Madagascar (Soderstrom \& Zuloaga 1989). Na Marambaia é encontrada na floresta atlântica de encosta, na borda e no interior da floresta, em indivíduos isolados ou formando pequenas populações, muito comum. Coletada com flores durante todo o ano.

Olyra latifolia é uma espécie com grande variação morfológica. $\mathrm{Na}$ área de estudo ocorrem dois morfotipos, um representado por plantas apoiantes com bainhas pubescentes, lâminas verdeopacas e espiguetas pistiladas com longas aristas esverdeadas, e outro representado por plantas eretas com bainhas hirsutas, lâminas verde-lustrosas e espiguetas pistiladas com curtas aristas vináceas.

\section{Parodiolyra Soderstr. \& Zuloaga}

Plantas perenes, monóicas, cespitosas, com ou sem rizomas curtos. Colmos eretos, ou geniculados na base, ou apoiantes, sem dimorfismo foliar. Bainhas foliares sem fímbrias no ápice; lâminas lanceoladas a oval-lanceoladas, base geralmente simétrica. Inflorescências paniculadas, terminais, ramos inferiores com espiguetas estaminadas, os superiores com espiguetas pistiladas, menos comumente com estaminadas inferiormente e pistiladas terminais. Espiguetas 1-floras, com flores unissexuadas. Espiguetas pistiladas com pedicelos filiformes, não espessados no ápice, com desarticulação abaixo das glumas, essas caindo com o antécio maduro; entrenó entre as glumas conspícuo e espessado, ápice da gluma inferior obtuso, agudo ou acuminado; antécio não estipitado, coriáceo, lanceolado, elíptico, oval ou oboval, comprimido dorsiventralmente, glabro ou piloso, liso, foveolado ou pontuado, sem manchas escuras na maturação. Espiguetas estaminadas de comprimento subigual às pistiladas ou mais longas, glumas ausentes ou presentes; antécio lanceolado, lema mútico ou aristado. Estames 3.

Gênero com cinco espécies neotropicais, distribuídas da Costa Rica até Paraguai e sul do Brasil (Judziewicz et al. 1999), representado por uma espécie na Marambaia.

3.1. Parodiolyra micrantha (Kunth) Davidse \& Zuloaga, Novon 9: 590. $1999 \quad$ Fig. 2a-f, 4j-1 Olyra micrantha Kunth in Humb., Bonpl. \& Kunth, Nov. Gen. Sp. 1: 199. 1816.

Plantas cespitosas, eretas, $150-200 \mathrm{~cm}$; colmos herbáceos a sublignificados, glabros ou pilosos, esverdeados, nós glabros. Bainhas foliares glabras, com pontuações esverdeadas, ciliadas em ambas as margens; lígula membranosa (1-)4-19(-27) mm compr.; pseudopecíolo 2-7(-8) mm compr., curtamente piloso; lâminas $(10,3-) 15,8-27,7(-41,5) \times(1-) 3,1-6,9(-9,5) \mathrm{cm}$, lanceoladas, base arredondada, leve a fortemente assimétrica, ápice acuminado, glabras em ambas as faces, às vezes escabras na face abaxial. Panícula 11,5-23(-33) × 4-16,5(-26) cm, aberta, terminal, ramos inferiores verticilados a alternos portando só espiguetas estaminadas, ramos superiores alternos, somente com espiguetas pistiladas ou, menos comumente, somente com estaminadas ou com estaminadas inferiormente e pistiladas terminais. Espiguetas pistiladas (6-)9-11,5 × (1,3-)1,8-2,2 mm, ovais a elípticas; glumas cartáceas, estramíneas, hirsutas, a inferior 5-nervada, com arista de 2,5-3,5(-6) $\mathrm{mm}$ compr., a superior 3-nervada, com arista de 1-2 mm compr.; antécio 2,9-3,3 × 1,5-1,7 $\mathrm{mm}$, elíptico, coriáceo, glabro, foveolado, com escavações arredondadas, esbranquiçado a castanho-alaranjado, lema com o ápice obtuso ou agudo, mútico ou aristado. Espiguetas estaminadas $7,5 \times 0,4-0,6 \mathrm{~mm}$, linear-lanceoladas, glumas ausentes; antécio membranáceo, hialino, com nervuras estramíneas, glabro, lema com arista de 3,5 mm compr., 3-nervado. Estames com anteras 


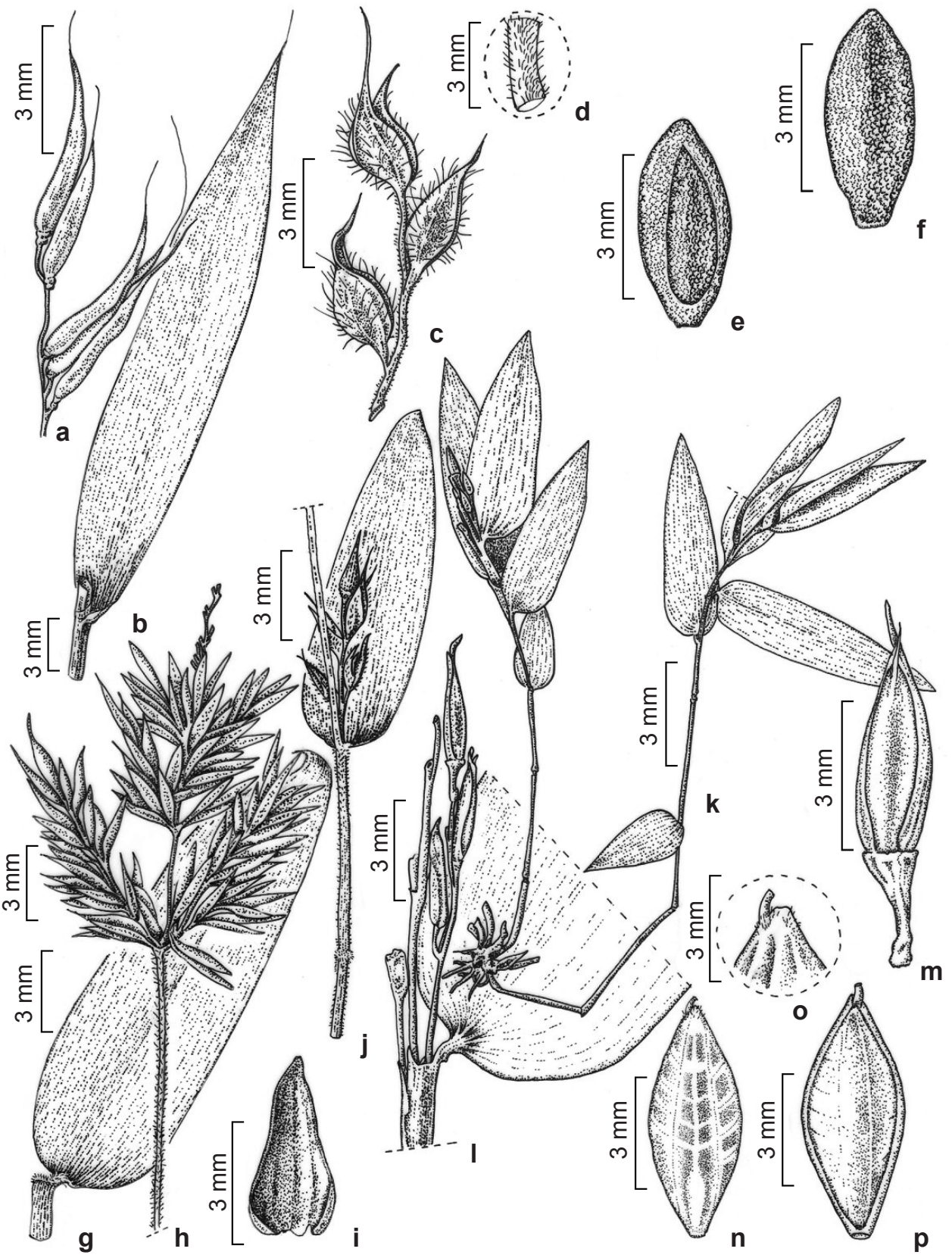

Figura 2 - a-f. Parodiolyra micrantha (Kunth) Davidse \& Zuloaga - a. ramo inferior da panícula com espiguetas estaminadas; b. folha; c. ramo superior da panícula com espiguetas pistiladas; d. ráquis hirsuta; e. antécio pistilado foveolado, vista ventral; f. antécio pistilado foveolado, vista dorsal. g-j. Raddia brasiliensis Bertol. - g. folha; h. panícula terminal com espiguetas estaminadas; i. gluma superior da espigueta pistilada; j. racemo axilar com espiguetas pistiladas. k-p. Reitzia smithii Swallen - k. hábito; 1 inflorescência; $m$. espigueta pistilada, vista ventral; $n$. antécio pistilado, vista dorsal; $o$. ápice do antécio pistilado; p. antécio pistilado, vista ventral. (a-f C. Silva \& N.M. Corrêa 169; g-j C. Silva \& A.C.C. Moreira 45; k-p C. Silva 192).

Figure 2 - a-f. Parodiolyra micrantha (Kunth) Davidse \& Zuloaga - a. panicle lower branch bearing staminate spikelets; b. leaf; c. panicle upper branch bearing pistillate spikelets; $d$. hirsute rachis; e. pitted pistillate anthecium, ventral view; f. pitted pistillate anthecium, dorsal view. g-j. Raddia brasiliensis Bertol. - g. leaf; h. terminal panicle bearing staminate spikelets; i. upper glume from a pistillate spikelet; j. axillary raceme bearing pistillate spikelets. k-p. Reitzia smithii Swallen -k. habit; 1 . inflorescence; m. pistillate spikelet, ventral view; n. pistillate anthecium, dorsal view; 0 . pistillate anthecium apex; p. pistillate anthecium, ventral view. (a-f C. Silva \& N.M. Corrêa 169; g-j C. Silva \& A.C.C. Moreira 45; k-p C. Silva 192). 
vináceas. Cariopse $2,5 \times 1 \mathrm{~mm}$, elíptica, castanhoescura.

Material selecionado: Mangaratiba, Ilha da Marambaia, sobre a ponte na trilha para a Gruta, $23^{\circ} 3^{\prime} 41,1$ "S 4358'38,5"W, 18.VIII.2009, fl., C. Silva et al. 103 (RBR); trilha próxima à Praia do Sino, 234'44,3"S 44¹9,9"W, 20.III.2010, fl., C. Silva \& N.M. Corrêa 169 (RBR); trilha da Senzala, 233'37,7'S 4358'45'W, 23.V.2009, C. Silva \& C.M.T. Silva 74 (RBR); trilha para o Pico da Marambaia, 234'16,3'S 4358'55,7'W, 19.III.2010, fl., C. Silva et al. 153 (RBR); Encosta de morro entre a Praia da Caetana e a Praia da Pescaria Velha, 234'21,2"'S 43059'57,7', 20.III.2010, C. Silva \& N.M. Corrêa 164 (RBR); trilha da Senzala, 8.XI.2008, fl., C. Silva \& A.C.C. Moreira 31 (RBR).

Material adicional examinado: BRASIL. ACRE: Sena Madureira, 27.IX.1980, fl., C.A. Cid \& B.W. Nelson 2541- $A$ (RB). AMAPÁ: Fronteira entre Brasil, Guiana Francesa e Suriname, 2.VIII.1972, fl., C. Sastre 1556 (RB). BAHIA: Ilhéus, Castelo Novo, 18.IX.1944, fl., $H$. Velloso 1099 (R). MINAS GERAIS: Poços de Caldas, 2350'20"S 46³3'53'W, 1.XII.1982, fl., H.F. Leitão Filho et al. 1843 (RB). PARÁ: Obidos, VII.1934, fl., J.R. Swallen 5090 (R). RIO DE JANEIRO: Rio de Janeiro, Serra do Mendanha, $23^{\circ} 17^{\prime \prime S} 43^{\circ} 17^{\prime} 17^{\prime \prime} \mathrm{W}, 23$.VIII.2008, fl., C.N. Fraga 2215 (RB).

Espécie presente na porção tropical da América do Sul, estendo-se até áreas subtropicais, com menor abundância. Na Marambaia é encontrada na floresta atlântica de encosta, na borda e no interior da floresta, formando grandes populações, muito comum. Coletada com flores e frutos durante todo o ano.

Parodiolyra micrantha pode ser reconhecida pelas panículas terminais amplas com espiguetas pistiladas hirsutas providas de antécio de superfície foveolada, o que pode ser observado no campo, após a separação das glumas.

\section{Raddia Bertol.}

Plantas perenes, monóicas, cespitosas, com ou sem rizomas curtos, raramente estoloníferas. Colmos eretos ou geniculados na base, com ou sem dimorfismo foliar. Bainhas foliares sem fímbrias no ápice; lâminas linear-lanceoladas, lanceoladas, oval-lanceoladas ou oblongas, base geralmente assimétrica. Inflorescências estaminadas paniculadas, terminais, menos comumente axilares; inflorescências pistiladas racemosas, axilares. Espiguetas 1-floras, com flores unissexuadas. Espiguetas pistiladas com pedicelos levemente espessados no ápice, com desarticulação acima das glumas que persistem na inflorescência após a queda do antécio maduro, glumas, às vezes, posteriormente caducas; entrenó entre as glumas inconspícuo, ápice da gluma inferior acuminado, caudado ou aristado; antécio não estipitado, coriáceo, lanceolado, elíptico ou oval, comprimido dorsiventralmente, glabro, liso, às vezes com manchas escuras na maturação. Espiguetas estaminadas ligeiramente menores ou maiores do que as pistiladas, glumas ausentes; antécio linear, lanceolado ou elíptico, lema mútico ou aristado. Estames 3.

Gênero com nove espécies exclusivas de áreas florestais, amplamente distribuídas no Brasil, uma delas, R. guianensis (Brongn.) Hitchc., ocorrendo também em áreas extrabrasileiras (Oliveira et al. 2008), representado por uma espécie na Marambaia.

4.1. Raddia brasiliensis Bertol., Opusc. Sci. 3: 410. 1819

Fig. 2g-j, 5a-d

Olyra floribunda Raddi, Agrostogr. Bras. 20-21. 1823. Olyra brasiliensis (Bertol.) Spreng., Syst. Veg. 4: Cur. Post 29. 1827.

Plantas cespitosas, eretas, com rizomas curtos, $40 \mathrm{~cm}$; colmos herbáceos, curtamente pilosos, nós pilosos, sem dimorfismo foliar. Bainhas foliares pilosas, mais densamente em ambas as margens e próximo ao ápice; lígula membranosociliada ca. 0,3 mm compr.; pseudopecíolo $1 \mathrm{~mm}$ compr., densamente piloso; lâminas 2,2-6,4(-9) $\times 1,1-2(-2,7) \mathrm{cm}$, oblongas, base arredondada, levemente assimétrica, ápice obtuso, apiculado, assimétrico, glabras na face ventral e pilosas na face dorsal. Panícula estaminada 2-3,2 × 1,5-2 cm, aberta, terminal, menos comumente axilar, ramos inferiores verticilados a subverticilados, ramos superiores alternos; racemos pistilados 1,5-2,5 $\times$ $0,5 \mathrm{~cm}$, axilares, parcialmente incluídos nas bainhas, com 4-6 espiguetas pistiladas. Espiguetas pistiladas 6-8 × 1,8-2 mm, oval-lanceoladas; glumas cartáceas, marrom-esverdeadas, densamente pilosas, tricomas ca. 0,5 mm, a inferior 5-nervada, com arista de ca. de 2,8 mm compr., a superior 3-nervada, mútica; antécio 4,3-4,5 × 1,3-1,5 $\mathrm{mm}$, oval-lanceolado, subcoriáceo, glabro, liso, esbranquiçado a esverdeado, com ou sem manchas escuras na maturação, lema com o ápice agudo. Espiguetas estaminadas 5,5 ×0,6 mm, lanceoladas, glumas ausentes; antécio membranáceo, hialino, com nervuras esverdeadas, pubescente, lema com arista de 0,5 mm compr., 3-nervado. Estames com anteras vináceas. Cariopse 2,8 × $1 \mathrm{~mm}$, elíptica, castanho-clara. 
Material selecionado: Mangaratiba, Ilha da Marambaia, Cachoeira da Gruta, 233'42,8"S 4358'34,7"W, 21.III.2010, fl., C. Silva \& N.M. Corrêa 184 (RBR); Cachoeira da Gruta, 233'42,5"S 4358'34,6"W, 19.XII.2010, fl., C. Silva \& N.M. Corrêa 233 (RBR); Cachoeira da Gruta, 233'43,3"S 4358'39,7"W, 8.XI.2008, fl., C. Silva \& A.C.C. Moreira 45 (RBR).

Material adicional examinado: BRASIL. ESPÍRITO SANTO: Colatina, Rio Doce, 1.XII.1943, fl., J.G. Kuhlmann 6579 (RB). RIO DE JANEIRO: Cabo Frio, Estrada antiga para Búzios, 28.VI.1995, fl., D. Araujo et al. 10317 (GUA).

Espécie presente no Brasil, nos Estados da Paraíba, Bahia, Mato Grosso, Espírito Santo e Rio de Janeiro (Soreng et al. 2000). Na Marambaia é encontrada na floresta atlântica de encosta próxima a cursos d'água, pouco comum, formando pequenas populações. Coletada com flores e/ou frutos de maio a agosto e de outubro a março.

Raddia brasiliensis pode ser reconhecida pelas lâminas foliares de ápice assimétrico e apiculado, panículas terminais com espiguetas estaminadas e racemos axilares com espiguetas pistiladas.

\section{Reitzia Swallen}

Plantas perenes, monóicas, cespitosas, rizomas ausentes. Colmos eretos ou geniculados na base, com dimorfismo foliar. Bainhas foliares sem fímbrias no ápice; lâminas oval-lanceoladas ou oblongo-lanceoladas, base levemente assimétrica. Inflorescências racemosas, terminais, menos comumente axilares, com espiguetas pistiladas pediceladas acompanhadas de 1-2 espiguetas estaminadas subsésseis. Espiguetas 1-floras, com flores unissexuadas. Espiguetas pistiladas com pedicelos espessados no ápice, com desarticulação abaixo das glumas, essas caindo com o antécio maduro; entrenó entre as glumas inconspícuo, ápice da gluma inferior agudo, atenuado ou acuminado; antécio não estipitado, coriáceo, elíptico a oblanceolado, comprimido dorsiventralmente, glabro, liso, com manchas escuras na maturação. Espiguetas estaminadas menores do que as pistiladas, glumas ausentes; antécio lanceolado, lema mútico. Estames 3.

Gênero monoespecífico, endêmico do Brasil, encontrado nos estados de Santa Catarina, São Paulo e Rio de Janeiro (Oliveira et al. 2006). A presença de manchas escuras nos antécios pistilados, na maturação, tem sido referida como de importância taxonômica para diferenciar este gênero dos demais gêneros de Olyreae (Calderón
\& Soderstrom 1980). Entretanto, isto foi verificado também em outros gêneros, tais como Olyra e Raddia, na análise dos materiais coletados na área e de outros depositados nos Herbários GUA, R e $\mathrm{RB}$, revelando-se um caráter inconsistente para este fim.

\subsection{Reitzia smithii Swallen, Sellowia 7: 8.1956}

Fig. 2k-p, 5e-g

Plantas cespitosas, eretas, base geniculada, 10-20(-45) cm; colmos herbáceos, com 1 linha longitudinal de tricomas curtos, nós glabros ou pilosos. Bainhas foliares glabras, ciliadas em ambas as margens e no ápice; lígula membranosa ca. 0,3 mm compr.; pseudopecíolo $1 \mathrm{~mm}$ compr., com tricomas na região mediana, em ambas as faces; lâminas 2,9-7,3(-9) × $(0,65-) 1-1,7(-2,3)$ $\mathrm{cm}$, oval a oval-lanceoladas, base arredondada a subcordada, assimétrica, ápice agudo a acuminado, face adaxial com tricomas curtos na nervura central, face abaxial com tricomas curtos na região entre as nervuras, face abaxial levemente esbranquiçada. Inflorescência $1,5-2,2(-3,5) \times 0,2-0,3 \mathrm{~cm}$, contraída, terminal, parcialmente incluída nas bainhas, com espiguetas pistiladas terminais, acompanhadas de 1-2 espiguetas estaminadas sésseis inferiormente. Espiguetas pistiladas 5-6 $\times 1-1,3 \mathrm{~mm}$, lanceoladas; glumas subcoriáceas, verde-acinzentadas, a inferior 5-nervada, com região apical levemente pubescente nas margens, acuminada, a superior 3-nervada, glabra, aguda; antécio 4,2 $\times 1 \mathrm{~mm}$, elíptico-lanceolado, coriáceo, glabro, liso, verde-acinzentado, lema com o ápice agudo. Espiguetas estaminadas $3 \times 0,5$ $\mathrm{mm}$, lanceoladas, glumas ausentes; antécio membranáceo, esverdeado, glabro, lema de ápice acuminado, 3-nervado. Estames com anteras amareladas. Cariopse não vista.

Material selecionado: Mangaratiba, Ilha da Marambaia, cachoeira entre a Praia da Caetana e a Praia da Pescaria Velha, 234'14,5"S 4359'48,5"W, 16.IV.2010, fl., C. Silva 192 (RBR); Cachoeira entre a Praia da Caetana e

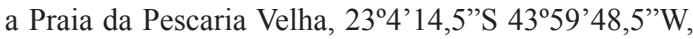
20.III.2010, fl., C. Silva \& N.M. Corrêa 163 (RBR).

Material adicional examinado: BRASIL. RIO DE JANEIRO: Bom Jesus do Itabapoana, Distrito de Carabuçu, 14.XII.1982, fl., L. Sérgio P. Sarahyba et al. 275 (GUA). SANTA CATARINA: Brusque, Azambuja, 27.III.1957, fl., L.B. Smith \& Pe. R. Klein 12255 (R); Iguape, Morro das Pedras, XI.1920, fl., A.C. Brade 8107 (R).

Espécie presente no Brasil, nos Estados de São Paulo, Rio de Janeiro e Santa Catarina 
(Oliveira et al. 2006). Na Marambaia é encontrada na floresta atlântica de encosta próxima a cursos d'água, pouco comum. A única população encontrada localiza-se próximo à área antropizada e, por isto, está em risco. Coletada com flores de fevereiro a abril, e em junho e novembro.

Reitzia smithii pode ser reconhecida pelo porte reduzido e inflorescências terminais inconspícuas entre as lâminas foliares.

\section{Subtribo Parianinae}

Plantas com bainhas foliares com o ápice fimbriado e espiguetas estaminadas e pistiladas em verticilos, arranjados em inflorescências espiciformes. Compreende dois gêneros (Eremitis e Pariana) encontrados somente na América do Sul (Soreng et al. 2000).

\section{Eremitis Döll}

Plantas perenes, monóicas, cespitosas, com ou sem rizomas curtos, ou estoloníferas. Colmos eretos a decumbentes, com dimorfismo foliar. Bainhas foliares fimbriadas no ápice; lâminas ovais a linear-lanceoladas, base geralmente assimétrica. Inflorescências espiciformes, terminais (às vezes também axilares), parcial a totalmente incluídas em bainhas foliares com lâminas rudimentares, às vezes em colmos floríferos decumbentes parcial a totalmente enterrados no solo (gerando cleistogamia) e com folhas reduzidas às bainhas, composta por verticilos de espiguetas; os superiores formados por espiguetas pistiladas sésseis acompanhadas de espiguetas estaminadas longo-pediceladas, com os pedicelos achatados e fusionados, formando um tubo; os inferiores formados por espiguetas estaminadas estéreis subsésseis. Espiguetas 1-floras, com flores unissexuadas. Espiguetas pistiladas sésseis, com desarticulação acima das glumas, caindo junto com os verticilos apicais e suas estruturas acessórias; entrenó entre as glumas inconspícuo, ápice da gluma inferior agudo; antécio não estipitado, coriáceo, lanceolado, levemente comprimido dorsiventralmente, glabro e liso, sem manchas escuras na maturação. Espiguetas estaminadas bem menores do que as pistiladas, glumas presentes; antécio oblongo, lema mútico, levemente emarginado. Estames 2.

Gênero com apenas uma espécie validamente descrita, Eremitis parviflora (Trin.) Calderón \& Soderstr., distribuído de Pernambuco ao Rio de Janeiro (Oliveira et al. 2006).

\subsection{Eremitis sp.}

Fig. 3a-i, 5h-m

Plantas cespitosas, eretas, $20-70 \mathrm{~cm}$; colmos herbáceos, com pilosidade inconspícua entre as nervuras, levemente vináceos, nós pilosos, com dimorfismo foliar. Bainhas foliares glabras no dorso, pilosas em ambas as margens e no ápice, fímbrias vináceas de 5-23 mm compr.; lígula membranosa ca. $0,8 \mathrm{~mm}$ compr.; pseudopecíolo 2,5 mm compr., piloso; lâminas 3,8-11,7 ×0,8-3,5 $\mathrm{cm}$, oval a oval-lanceoladas, base arredondada a cuneada, assimétrica, ápice agudo a acuminado, face adaxial esparsamente pilosa, face abaxial densamente pilosa sobre a nervura central e pubescente sobre o restante da lâmina, levemente esbranquiçada. Inflorescência $2,5-3,5(-4,4) \times$ $0,4 \mathrm{~cm}$, terminais, às vezes também axilares, com 1(-2) verticilo(s) superior(es) portando (1-)2 espiguetas pistiladas sésseis rodeadas por 5 espiguetas estaminadas, essas com os pedicelados achatados e fusionados formando um tubo que encobre as pistiladas, ca. $10 \mathrm{~mm}$, curtamente piloso; e 3 verticilos inferiores com 2-3 espiguetas estaminadas rudimentares. Espiguetas pistiladas 8-10 × 2,5-3 mm, lanceoladas; glumas ca. $7 \mathrm{~mm}$ compr., subcoriáceas, esbranquiçadas, curtamente pilosas próximo ao ápice, 3-nervadas, com o ápice agudo; antécio $8-10 \times 2,5-3 \mathrm{~mm}$, lanceolado, coriáceo, glabro, liso, esbranquiçado a castanhoclaro, lema com o ápice acuminado. Espiguetas estaminadas 4-5 mm compr., oblongas, glumas presentes, coriáceas, algo menores do que o antécio, castanho-escuras, pilosas nas margens, ápice agudo; antécio coriáceo, castanho-escuro, curtamente piloso, lema 3-nervado. Estames com anteras esbranquiçadas a amareladas. Cariopse 5,2 $\times 2,2 \mathrm{~mm}$, oblongo-lanceolada, castanho-clara.

Material selecionado: Mangaratiba, Ilha da Marambaia,

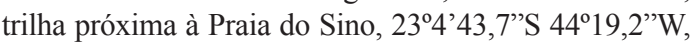
17.VI.2010, fl., C. Silva \& F.M. Ferreira 200 (RBR);

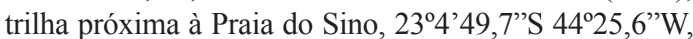
20.III.2010, fl., C. Silva \& N.M. Corrêa 171 (RBR); trilha entre a Praia da Pescaria Velha e a Praia do Sino, 234ㄴ $48^{\prime \prime}$ S 4400'23”'W, 16.IV.2010, fl., C. Silva 193 (RBR).

Na Marambaia, Eremitis sp. foi encontrada na floresta atlântica de encosta, na borda e no interior da floresta, em apenas uma área situada na transição com a restinga, de solo arenoso com pequena camada de matéria orgânica. Esta área vem sofrendo forte ação antrópica, ameaçando a sobrevivência da população existente. Coletada com flores e/ou frutos em abril e junho.

Esta espécie apresenta duas espiguetas pistiladas por verticilo, e não somente uma como em 


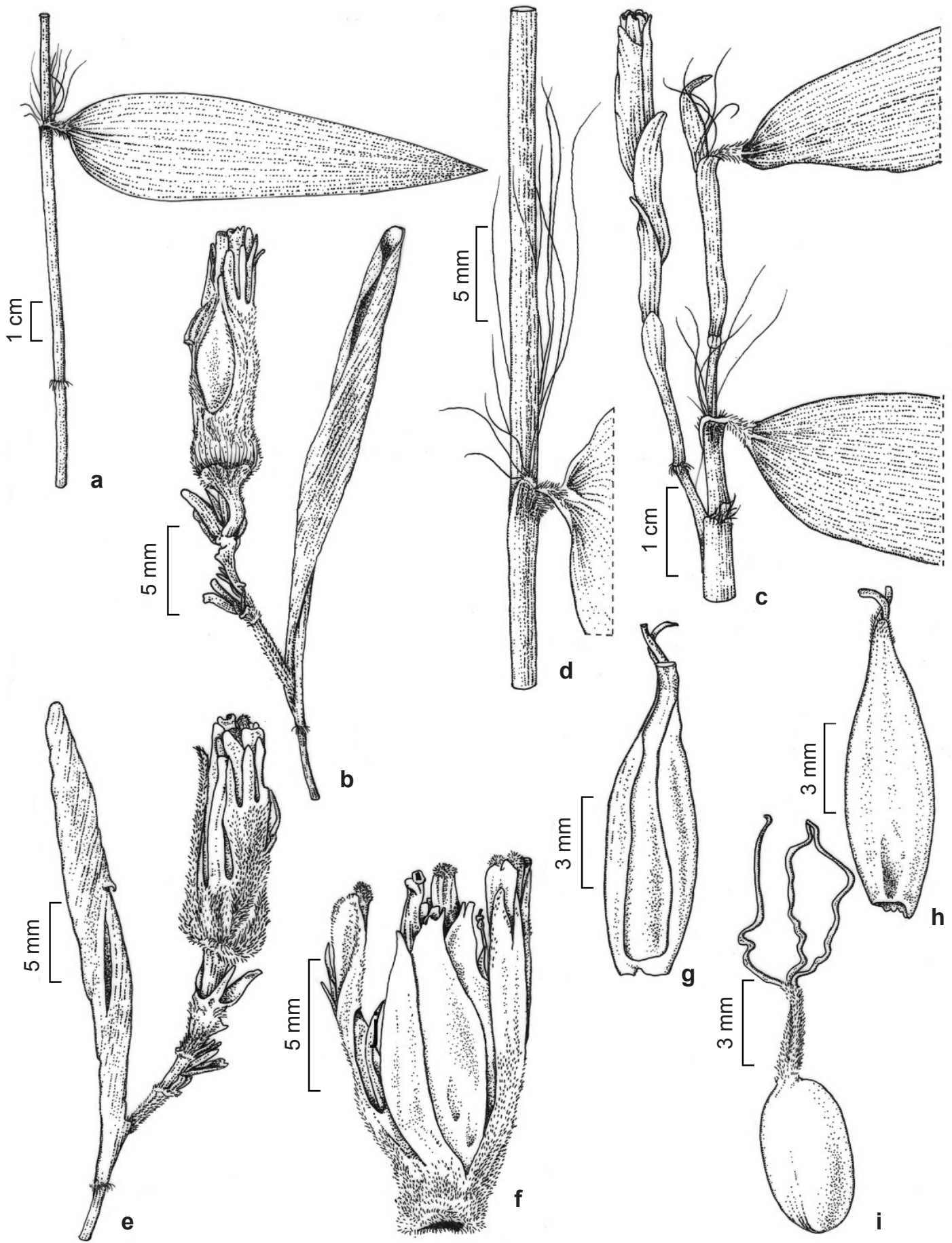

Figura 3 - a-i. Eremitis sp. - a. folha; b. inflorescência destacada da bainha foliar, vista ventral; c. inflorescência; d. fímbrias no ápice da bainha foliar; e. inflorescência destacada da bainha foliar, vista dorsal; f. verticilo de espiguetas superior; g. antécio pistilado, vista ventral; h. antécio pistilado, vista dorsal; i. cariopse em desenvolvimento, com estilete e estigmas. (a-i C. Silva 193).

Figure 3 - a-i. Eremitis sp. - a. leaf; b. inflorescence detached from the leaf sheath, ventral view; c. inflorescence; d. fimbriae on the leaf sheath apex; e. inflorescence detached from the leaf sheath, dorsal view; f. upper spikelets cluster; g. pistillate anthecium, ventral view; h. pistillate anthecium, dorsal view; i. developing caryopsis with style and stigmas. (a-i C. Silva 193). 

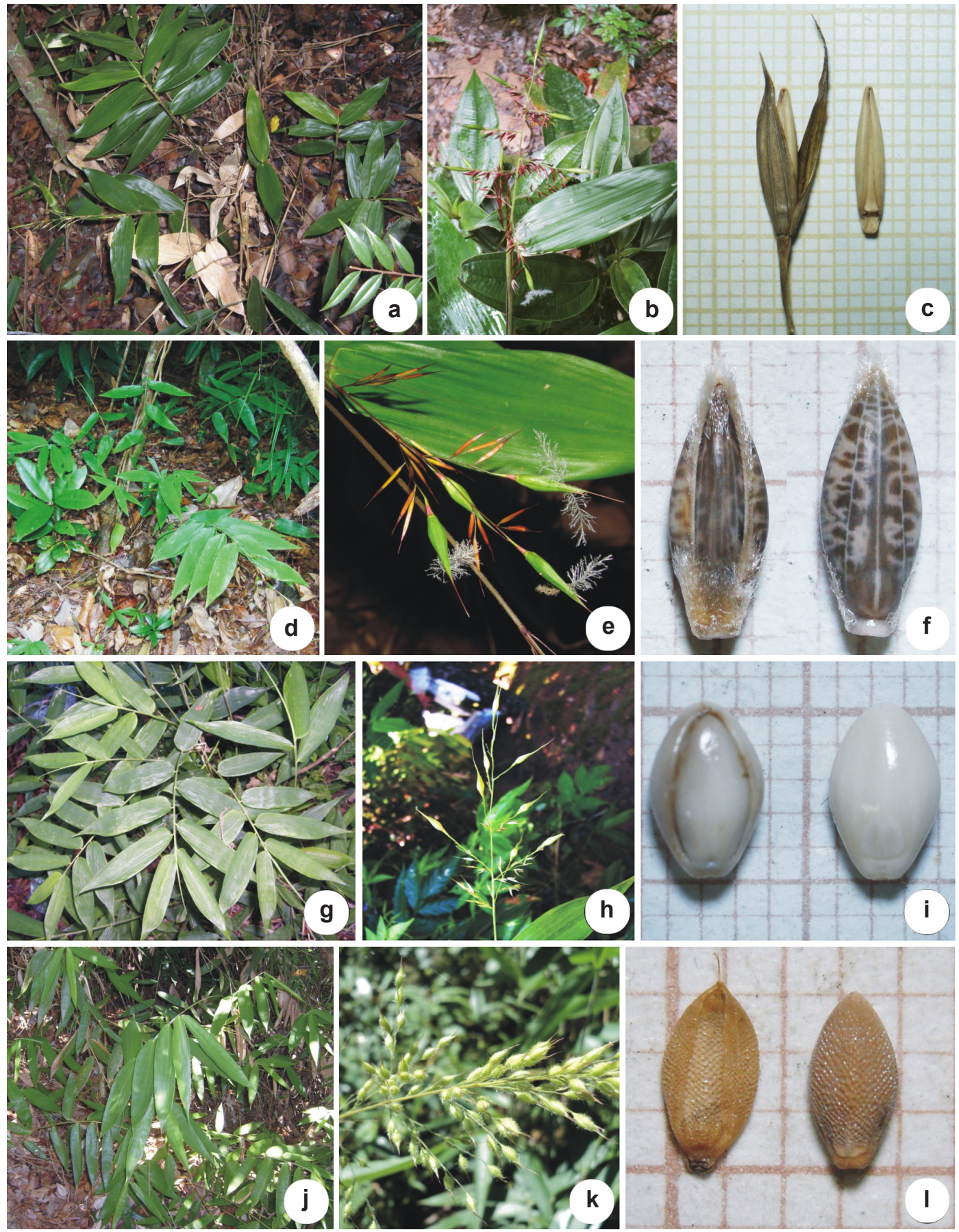

Figura 4 -a-c. Cryptochloa capillata (Trin.) Soderstr. - a. hábito; b. panícula terminal; c. espigueta e antécio pistilados. d-f. Olyra humilis Nees - d. hábito; e. panícula; f. antécio pistilado maculado, vistas ventral (esquerda) e dorsal (direita). g-i. Olyra latifolia L. -g. hábito; h. panícula; i. antécio pistilado, vistas ventral (esquerda) e dorsal (direita).j-1. Parodiolyra micrantha (Kunth) Davidse \& Zuloaga-j. hábito; k. panícula; l. antécio pistilado foveolado, vistas ventral (esquerda) e dorsal (direita). Quadrículas $1 \times 1 \mathrm{~mm}$. (a-c C. Silva \& A.C.C. Moreira 47; d-f C. Silva \& F.M. Ferreira 202; g-i C. Silva \& N.M. Corrêa 168; j-1 C. Silva \& N.M. Corrêa 169). Figure 4 - a-c. Cryptochloa capillata (Trin.) Soderstr. - a. habit; b. terminal panicle; c. pistillate spikelet and anthecium. d-f. Olyra humilis Nees - d. habit; e. panicle; f. mottled pistillate anthecium, ventral (left) and dorsal (right) view. g-i. Olyra latifolia L. - g. habit; h. panicle; i. pistillate anthecium, ventral (left) and dorsal (right) view. j-l. Parodiolyra micrantha (Kunth) Davidse \& Zuloaga - j. habit; k. panicle; 1. pitted pistillate anthecium, ventral (left) and dorsal (right) view. Squares $1 \times 1 \mathrm{~mm}$. (a-c C. Silva \& A.C.C. Moreira 47; d-f C. Silva \& F.M. Ferreira 202; g-i C. Silva \& N.M. Corrêa 168; j-1 C. Silva \& N.M. Corrêa 169). 

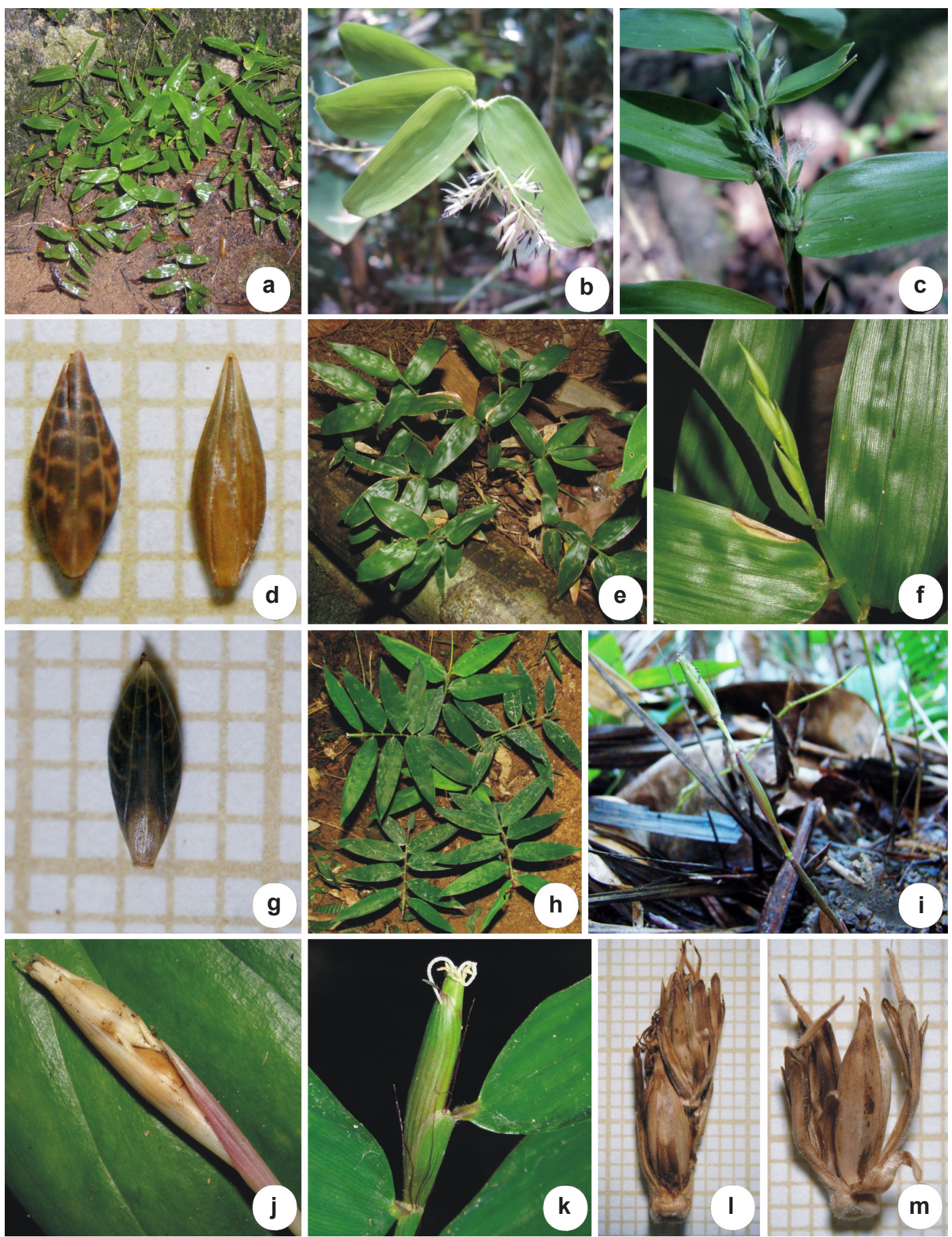

Figura 5-a-d. Raddia brasiliensis Bertol. - a. hábito; b. panícula estaminada terminal; c. racemos pistilados axilares; d. antécio pistilado, vistas dorsal (maduro, à esquerda) e ventral (imaturo, à direita). e-g. Reitzia smithii Swallen - e. hábito; f. inflorescência; g. antécio pistilado maculado. h-m. Eremitis sp. - h. hábito; i. colmo fértil afilo e decumbente; j. inflorescência subterrânea; k. inflorescência terminal; 1. verticilos superiores de espiguetas; m. verticilo superior de espiguetas (um antécio pistilado removido). Quadrículas $1 \times 1 \mathrm{~mm}$. (a-d C. Silva \& A.C.C. Moreira 45; e-g C. Silva 192; h-m C. Silva \& F.M. Ferreira 200). Figure 5 - a-d. Raddia brasiliensis Bertol. - a. habit; b. staminate terminal panicle; c. axillary pistillate racemes; d. pistillate anthecium, dorsal (mature, on the left) and ventral (immature, on the right) view. e-g. Reitzia smithii Swallen-e. habit; f. inflorescence; g. mottled pistillate anthecium. h-m. Eremitis sp. - h. habit; i. fertile decumbent aphyllous culm; j. underground inflorescence; k. terminal inflorescence; 1 . upper spikelets clusters; m. upper spikelets cluster (one pistillate anthecium removed). Squares $1 \times 1 \mathrm{~mm}$. (a-d C. Silva \& A.C.C. Moreira 45; e-g C. Silva 192; h-m C. Silva \& F.M. Ferreira 200). 
E. parviflora. Apresenta ainda inflorescências desde incluídas até totalmente livres das bainhas foliares terminais. Além disso, foi observada a presença de gineceu nas espiguetas estaminadas dos verticilos superiores (Fig. $5 \mathrm{~m}$ ) e de uma estrutura semelhante a uma cariopse (Fig. 5j). Porém, estudos - como ontogenia, por exemplo - devem ser conduzidos nesse sentido para que tal fato seja confirmado. São necessárias mais análises e comparação com outros espécimes de Eremitis para o melhor entendimento da morfologia das estruturas reprodutivas deste táxon. Estudos já estão sendo conduzidos para a delimitação taxonômica desta espécie.

\section{Agradecimentos}

Aos colegas e amigos que ajudaram nas coletas, em especial à Nadjara M. Corrêa. À Fabrício M. Ferreira pela ajuda em Eremitis e pela concessão de fotos (Figuras 4d-e; 5e-f,h-k). À Dra. Reyjane Patrícia de Oliveira pelas valiosas sugestões. Aos professores e funcionários do Departamento de Botânica da UFRRJ. Ao Centro de Avaliação do Exército (CAEx) e ao Centro de Adestramento da Ilha da Marambaia (CADIM) pelo apoio logístico nas atividades de campo. Ao PROIC - UFRRJ pela bolsa concedida ao primeiro autor e ao $\mathrm{CNPq}$ pela bolsa concedida à terceira autora. À Paula Calixto e Glória Gonçalves pelas ilustrações botânicas.

\section{Referências}

Calderón, C.E. \& Soderstrom, T.R. 1980. The genera of Bambusoideae (Poaceae) of the american continent: keys and comments. Smithsonian Contributions to Botany 44: 1-27.

Clark, L.G. 2009. Subfamilial classification of the Poaceae, with emphasis on the Bambusoideae. In: Moura, C.W.N.; Silva, T.R.S.; Giulietti-Harley, A.M. \& Santos, F.A.R. (eds.). Congresso Nacional de Botânica, 60, 2009, Bahia. Botânica Brasileira: futuro e compromissos. Resumos expandidos em DVD: 218-222.

Clark, L.G. \& Oliveira, R.P. 2001. Cryptochloa. In: Longhi-Wagner, H.M.; Bittrich, V.; Wanderley, M.G.L. \& Shepherd, G.J. (eds.) 2001. Poaceae. Flora Fanerogâmica do estado de São Paulo. Hucitec, São Paulo. Pp. 43-44.

Clayton, W.D.; Harman, K.T. \& Williamson, H. 2006 (onwards). GrassBase - The Online World Grass Flora. Disponível em: <http://www.kew.org/data/ grasses-db.html>. Acesso em Ago 2010.

Conde, M.M.S.; Lima, H.R.P. \& Peixoto, A.L. 2005. Aspectos Florísticos e Vegetacionais da Marambaia,
Rio de Janeiro. In: Menezes, L.F.T.; Peixoto, A.L. \& Araujo, D.S.D. (eds.). História natural da Marambaia. EDUR, Seropédica. Pp. 133-168.

Filgueiras, T.S. \& Santos-Gonçalves, A.P. 2004. A checklist of the basal grasses and bamboos in Brazil. The Journal of the American Bamboo Society 18: 7-18.

Fundação SOS Mata Atlântica/INPE. 2008. Atlas dos remanescentes florestais da Mata Atlântica: Período 2000-2005. Disponível em <www.sosmatatlantica. org.br>. Acesso em Ago 2010.

GPWG (Grass Phylogeny Working Group). 2001. Phylogeny and subfamilial classification of the grasses (Poaceae). Annals of the Missouri Botanical Garden 88: 373-457.

IUCN. 2001. IUCN Red List Categories and Criteria: Version 3.1. IUCN Species Survival Commission. IUCN, Glandand and Cambridge. $35 \mathrm{p}$.

IUCN. 2011. Guidelines for Using the IUCN Red List Categories and Criteria. Version 9.0. IUCN Standards and Petitions Subcommittee. Disponível em <http://www.iucnredlist.org/documents/ RedListGuidelines.pdf>. Acesso em Nov 2011.

Judziewicz, E.J.L.; Clark, L.G.; Londoño, X. \& Stern, M.J. 1999. American Bamboos. Smithsonian Institution Press, Washington, D.C. 392p.

Longhi-Wagner, H.M. 2011. Poaceae: an overview with reference to Brazil. Rodriguésia 63(1): 89-100.

Longhi-Wagner, H.M.; Bittrich, V.; Wanderley, M.G.L. \& Shepherd, G.J. (eds.) 2001. Poaceae. In: Wanderley, M.G.L.; Shepherd, G.J. \& Giulietti, A.M. (coords.). Flora Fanerogâmica do Estado de São Paulo. Hucitec, São Paulo. 292p.

Menezes, L.F.T. \& Araujo, D.S.D. 1999. Estrutura de duas formações vegetais do cordão externo da Restinga de Marambaia, RJ. Acta Botanica Brasilica 13: 233-235.

Missouri Botanical Garden (MBG). 2010. TROPICOS database. Disponível em: <http://www.tropicos. org $>$. Acesso em Ago 2010.

MMA - Ministério do Meio Ambiente. 2008. Espécies da flora brasileira ameaçadas de extinção. Instrução normativa n. 6, de 23 de setembro de 2008. Disponível em $<$ http://www.mma.gov.br $>$. Acesso em Nov 2011.

Oliveira, R.P. 2001. A tribo Olyreae (Poaceae: Bambusoideae) no Estado da Bahia, Brasil. Dissertação de mestrado. Universidade Estadual de Feira de Santana, Feira de Santana. 190p.

Oliveira, R.P.; Wagner, H.M.L. \& Jardim, J.G. 2006. Diversidade e conservação dos bambus herbáceos (Poaceae: Bambusoideae: Olyreae) da Mata Atlântica, Brasil. In: Simpósio Nacional sobre bambus, 2006, Brasília. Anais do Seminário Nacional "Bambu: estruturação da rede de pesquisa 
e desenvolvimento". Universidade de Brasília, Brasília. Pp. 62-66.

Oliveira, R.P.; Wagner, H.M.L. \& Leite, K.R.B. 2008. A contribuição da anatomia foliar para a taxonomia de Raddia (Poaceae: Bambusoideae: Olyreae). Acta Botanica Brasilica 22: 1-19.

Oliveira, R.P.; Wagner, H.M.L.; Filgueiras, T.S.; Mota, A.C.; Viana, P.L. 2009. Poaceae. In: Giulietti, A.M.; Rapini, A.; Andrade, M.J.G.; Queiroz, L.P. \& Silva, J.M.C. (org.) Plantas raras do Brasil. Conservação Internacional do Brasil, Belo Horizonte. Pp. 326340 .

Sánchez-Ken, J.G. \& Clark, L.G. 2010. Phylogeny and a new tribal classification of the Panicoideae s.l. (Poaceae) based on plastid and nuclear sequence data and structural data. American Journal of Botany 97: 1732-1748.

Soderstrom, T.R. \& Zuloaga, F.O. 1989. A revision of the genus Olyra and the new segregate genus Parodiolyra (Poaceae: Bambusoideae: Olyreae). Smithsonian Contributions to Botany 69: 1-79.
Soreng, R.J.; Davidse, G.; Peterson, P.M.; Zuloaga, F.O.; Judziewicz, E.J.; Filgueiras, T.S. \& Morrone, O. 2000 (onwards). Catalogue of New World Grasses (CNWG). Disponível em $<$ http:// www.tropicos.org/project/cnwg>. Acesso em Ago 2010.

Sungkaew, S.; Stapleton, C.M.A.; Salamin, N. \& Hodkinson, T.R. 2009. Non-monophyly of the woody bamboos (Bambuseae; Poaceae): a multi-gene region phylogenetic analysis of Bambusoideae s.s. Journal of Plant Research 122: 95-108.

Thiers, B. (continuously updated). Index Herbariorum: A global directory of public herbaria and associated staff. New York Botanical Garden's Virtual Herbarium. Disponível em $<$ http://sweetgum.nybg. org/ih/>. Acesso em 20 Ago 2010.

Zhang, W. \& Clark, L.G. 2000. Phylogeny and classification of the Bambusoideae (Poaceae). In: Jacobs, S.W.L. \& Everett, J.E. (eds.). Grasses: systematics and evolution. CSIRO, Collingwood. Pp. 35-42.

Lista de Exsicatas

Almeida, C.: 219 (3.1); Amaral, I.L.: 1077 (2.2); Araujo, D.S.D.: 188 (1.1); 915 (1.1); 1726 (1.1); 3372 (2.2); 10317 (4.1); Black: 59 (2.2); Brade, A.C.: 8107 (5.1); Carauta, J.P.P.: 5333 (2.2); Chase, M.A.: 8965 (2.1); Cid Ferreira, C.A.: 2541-a (3.1); Fraga, C.N.: 2215 (3.1); Freitas Junior, J.L.: 2 (3.1); Goeldi, A.: 300 (3.1); Heringer, E.P.: 18561 (3.1); Irmão Teodoro: 633 (3.1); Irwin, H.S.: s.n. RB 161747 (2.1); Jangoux, J.: 768 (1.1); Kuhlman, J.G.: 1700 (1.1); 6218 (1.1); 6579 (4.1); RB 77610 (2.1); Leitão, H.F.: 1843 (3.1); Lima, A.: 60-3544 (3.1); Lima, H.C.: 686 (3.1); 1757 (2.2); 1960 (1.1); Luetzelburg, P. von: 21359-b (3.1); 21473 (2.2); Nee, M.: 25093 (2.2); Nelson, B.: 715 (2.2); Platais, G.H.: 3 (3.1); Plaumann, F.: 323 (2.1); Quarín, C.L.: 1163 (2.1); Rosa, N.A.: 2139 (3.1); Sampaio, A.: 5946 (2.1); Sarahyba, L.S.P.: 275 (5.1); 816 (5.1); Sastre, C.: 1556 (3.1); Sem coletor: R 4098 (3.1); R 46693 (3.1); R 46694 (3.1); R 46713 (3.1); RB 16330 (3.1); RB 76094 (3.1); RB 135601 (3.1); Silva, C.: 31 (3.1); 35 (2.2); 45 (4.1); 46 (2.1); 47 (1.1); 73 (2.2); 74 (3.1); 81 (2.2); 103 (3.1); 152 (1.1); 153 (3.1); 163 (5.1); 164 (3.1); $168(2.2) ; 169$ (3.1); $171(6.1) ; 184$ (4.1); 192 (5.1); 193 (6.1); 200 (6.1); 202 (2.1); 233 (4.1); 241 (2.1); 243 (1.1); Smith, L.B.: 12255 (5.1); 12529 (2.1); 12662 (2.1); 12892 (2.1); 12930 (2.1); Soderstrom, T.R.: 1850 (1.1); 1899 (3.1); 1910 (1.1); 1916 (1.1); 1961 (1.1); 1983 (3.1); 1988 (2.1); Sucre, D.: 2112 (2.2); 5027 (1.1); 7029 (3.1); 7029 (1.1); 7684 (3.1); 11406 (1.1); Swallen, J.R.: 3425 (1.1); 5090 (3.1); Thomas, W.W.: s.n. RB 403542 (2.2); Velloso, H.P.: 1099 (3.1); Vieira, G.: 437 (2.2). 